\title{
The Paleolithic in Hungary
}

\author{
György Lengyel
}

Institute of Systematics and Evolution of Animals, Polish Academy of Sciences, Kraków, Poland

\section{Introduction/historical background}

Systematic Paleolithic research in Hungary began at the end of the $19^{\text {th }}$ century when three bifacial knapped lithic tools were found in Miskolc (northeast Hungary) during building the house of János Bársony (prosecutor of Miskolc) on the right bank of the Szinva Creek in the center of the town. Due to their shapes, Ottó Herman (1835-1914, ornithologist, arachnologist, ichthyologist, ethnographic and also a politician), the polyhistor of Miskolc, classified the three finds as Paleolithic handaxes, similar to those found in the Somme River terraces in France. Critics doubted the Pleistocene origin of the finds and Herman's claim that humans lived in Hungary during the Paleolithic. To find solid evidence for the existence of Paleolithic human population in Hungary, Herman took advantage of his political connections in Ignác Darányi (1849-1927), minister of agriculture, who encouraged the Royal Geological Institute of Hungary to launch excavations in the karstic caves of the Bükk Mountains in 1906. This action aimed at finding remains of Palaeolithic human cultures in Pleistocene geological depositional environment. The only person at the Royal Geological Institute of Hungary with an interest in cave excavations was Ottokár Kadić (1876-1957), born to a Hungarian-Croatian family. Kadić graduated as a zoologist specialized in insect anatomy, but also had interest in paleontology and prehistory. The latter field increasingly occupied his scientific interest since he reported upon of the discoveries of Neanderthal remains at Krapina Cave in Croatia in 1899. The first successful excavation in the Bükk Mountains which unearthed lithic tools from within Pleistocene layers was carried out at Szeleta Cave between 1907 and 1913. Kadić found bifacial laurel leaf points together with cave bear remains in the first season. The Pleistocene age of the assemblage became internationally accepted in 1911 at a paleoanthropological conference held in Tübingen, Germany. After the breakthrough of the Szeleta finds into the international research, Kadić excavated further caves in the Bükk Mountains: Peskő (1912-1942), Büdöspest (1913-1927), Herman Ottó (1915-1916) and Subalyuk (1932). Jenő Hillebrand (1884-1950), anthropologist, the head of the archaeological division at the Hungarian National Museum, joined Kadić at the Szeleta excavations and then started his own researches in Bükk Mountains 
at Balla Cave (1909-1913) and Istállóskő Cave (1912-1917), Jankovich Cave (1913-1925) and Kiskevély Cave (1912-1914) in Transdanubia and Dzeravá skala (back then Pálffy Cave) in western Slovakia in the Lesser Carpathians. Further pioneers in Palaeolithic research in Hungary who conducted excavation before World War II (WWII) were Tivadar Kormos (Tata, Pilisszántó Rockshelter), Andor Saád (Diósgyőr-Tapolca Cave, Szeleta Cave, Istállóskő Cave), Géza Megay (Görömböly-Tapolca Cave), István Gaál (Szelim Cave) and Sándor Gallus (Ságvár). The common in all the researchers active before WWII is that they were self-trained archeologists.

\section{Definition}

\section{Lower Paleolithic}

The only reliably dated Lower Palaeolithic site of Hungary is located in Vértesszőlős, western Hungary. The human occupations were found in a travertine quarry and the formation of the rock dates back to the Middle Pleistocene. Today the site is located in the open-air exhibition area of the Hungarian National Museum. László Vértes (1914-1968) excavated the site between 1963 and 1968 (Kretzoi \& Dobosi 1990) and recovered four loci (sites) within the quarry out of which site I and III were the most abundant in settlement remains. Site I embedded four archaeological layers and site III did five. In the section of site I, layer 3 was covered by loess and layer 4 situated on top of the loess. Besides the archaeological remains, the travertine beds preserved an important set of Middle Pleistocene vegetal imprints and animal footprints. The most important archaeological assemblage from the site, however, consists of five fragments of teeth of a young individual and an occipital bone of an adult nicknamed Sámuel / $\mathrm{a} a: m u \varepsilon 1 /$. Four teeth fragments were found at site I in layer 1 and the fifth fragment among travertine debris collected from the vicinity of the finding area of the other four fragments. The occipital bone lay eight meters outside of site 1 within the travertine. According to the anatomical features, the occipital bone belongs to a Homo heidelbergensis that bore already some characters of the Neanderthals (Kretzoi \& Dobosi 1990). The area of the site seems to have been favored by herbivores due to vegetal resources and access to water and therefore carnivores and humans could have been attracted by the visits of herbivores. The large mammal remains (bison, horse, rhino, deer) in the archaeological layers were found severely smashed. However, the accumulation of the bones could have only partially been related with human activity. Natural processes were also active in the formation of the archaeological record (Kretzoi \& Dobosi 1990). Besides the traces of on bone breakage, the lithic artifacts and burnt 
bone heaps interpreted as hearths are also clear evidences of human settlements. The human occupations were dated to between ca. 200 and 350 kya with U-Th series (Kretzoi \& Dobosi 1990). Recently, the travertine that included the human occipital bone was dated to $315 \mathrm{kya}$ and the earliest cultural layer to 328 kya (Kele et al. 2016). According to the sedimentation in site I, the human occupation started in the OIS 9 warm period and ran into the cold OIS 8 . The lithic artifacts were made of small pebbles of radiolarite and quartzite, thus the toolkit is on average, small ca. $3 \mathrm{~cm}$. Frequent types are choppers, chopping tools, notched and denticulated tools (often pointed) and scrapers. Vértesszölös hominins utilized a similar pebble technology to the Middle Palaeolithic Neanderthals dated to the OIS 5 at the nearby Tata (Borel et al. 2017). This sliced pebbles to obtain blanks with cortical surfaces and removed flakes in a manner similar to discoid and half discoid debitage. Also, angular fragments were obtained by bipolar flaking.

\section{Middle Palaeolithic}

Middle Palaeolithic (MP) sites in Hungary can be divided into three broad cultures: Mousterian, Taubachian and a bifacial MP.

The Mousterian has two archaeological manifestations: the typical Mousterian and the Quina type Mousterian. The only site where both types were found in superposition is Subalyuk Cave, Bükk Mountains. The typical Mousterian was recovered from layers 1-7 and the Quina Mousterian from layers 8-14 (Mester \& Patou-Mathis 2016; N.B. the numbering of the layers is ordered from bottom to top). Tentatively, layers $1-3$ can be dated on the basis of the fauna to OIS 5e, layer 4 to OIS 5b, layers 5-6 to OIS 5a, layers 7-13 to OIS 4 and layer 14 to OIS 3 . Zooarchaeological studies illustrated that the cave was periodically used as a den for wolves, hyenas and cave bears (Mester \& Patou-Mathis 2016). Humans occupied the cave rarely but when used, it was occupied seasonally and most archaeological remains were formed during ephemeral visits related to hunting. The typical Mousterian assemblages are accompanied by alpine ibex, chamois, red deer, aurochs, horse and woolly rhinoceros. The lithic assemblage of the typical Mousterian employed Levallois technology but flakes were also made using the discoidal method. The toolkit is composed of sidescrapers and Mousterian points and the blanks of the tools are often elongated.

The Quina Mousterian assemblages at Subalyuk Cave are accompanied by the same spectra of herbivores. The lithic tools were mostly made by the discoid and Quina methods, but remnants of Levallois technology were also found. Accordingly, many of the tools were made on thick, wide flakes. Quina type sidescrapers dominate these assemblages. Remarkable finds 
of the Quina Mousterian are the skeletal remains of two individuals of Neanderthals, an adult female and an infant (Tillier et al. 2006). The adult is represented by the mandible, a few vertebral fragments (atlas in three parts, three bodies, one spine process of a thoracic vertebra), the manubrium sterni, the sacrum, the left patella, fragments of a left second metacarpal and left proximal phalanx, the complete right second and left fourth metatarsal and a fragment of right third metatarsal. Compared to western European remains, the Subalyuk Neanderthal adult is less robust. One modern-like feature of the skeleton is the presence of an incurvatio mandibulae anterior (Tillier et al. 2006). The juvenile skeletal remains are represented by a cranium with two maxilla and the left nasal bone. Analyses of the human bone deposition supposed that the child was buried and the adult body lay on the cave floor uncovered (Mester \& Patou-Mathis 2016).

Further typical Mousterian finds from Hungary are sporadic but more abundant evidences were found for Quina Mousterian occupations. The largest site after Subalyuk Cave was found at Érd in the Transdanubia, western Hungary, excavated by Veronika Gábori-Csánk (19291996) (Mester \& Moncel 2006). The site is found in open-air embedded in loess. The human occupations originally were interpreted as a cave bear hunting camps and zooarchaeological analyses revealed that the site alternatively was occupied by denning cave bears, hyaenas, and humans (Daschek 2014). Besides the wealth of cave bear bones, archaeological remains are knapped quartzite tools made of pebbles. The archaeological finds are found in six levels embedded within three stratigraphic units. The flakes were produced with semi-discoid, discoid and Quina methods; the tools are most frequently sidescrapers. Two levels were dated with the decay counting radiocarbon method on charcoals, but the dates $35 \mathrm{ka}$ and $44 \mathrm{ka}$ uncal BP seem young compared to the age estimated on the basis of the stratigraphy to the Lower Pleniglacial period ca $60 \mathrm{ka}$.

The largest site of Taubachian in Hungary is Tata (Borel et al. 2017). Tata, similarly to Vértesszőlős, was also found intercalated by travertine beds. Tata has been excavated since the early $20^{\text {th }}$ century to present through several campaigns. The fauna consisted mostly of mammoth and horse remains and a remarkable find is a mammoth tooth plate polished and stained with red ochre. The travertine beds delimiting the archaeological layer were dated to 116 kya 3 m below and 76 kya $1 \mathrm{~m}$ above with U-Th series, therefore, the archaeological layer is of Early Weichselian age. With this dating, this is the only reliably radiometrically dated MP site in Hungary. The lithic tools were made of small radiolarite pebbles giving the industry a microlithic character. The cores were exploited from two or more striking platforms and several items showed similarity to discoid and half discoid method. The technological root of the 
Taubachian industry was found in the Lower Palaeolithic, for instance Vértesszőlős site dated to MIS 9. Frequent tool types are sidescrapers, offset points, denticulated flakes and notches. Bifacial retouching also occurs on a few tools.

The third type of MP human culture produced bifacially shaped lithic tools. Out of the bifacial MP cultures, the earliest could be the Jankovichian. The culture received its name from Jankovich Cave in the Transdanubian Range, Gerecse Mountains. Gábori-Csánk (1993) pointed out that the bifacial tools were similar to those found in the late MP Central European bifacial leaf point industries, today called Micoquian. A striking character of the Jankovichian culture is the bifacial leaf-shaped tool and the presence of Levallois technology. At Remete-Felső Cave, Jankovichian tools were found associated with two incisors and a canine of Homo, which do not have distinct features of either Neanderthals or modern humans (Tillier et al. 2006).

Another bifacial phenomenon in the Hungarian MP is called the Bábonyian. Several open-air sites have been found along the eastern margin of the Bükk Mountains though the only excavated one is at the eponymous site in the village of Sajóbábony (Ringer \& Adams 2000). The Bábonyian also was defined as a variant of the Central European Micoquian (Ringer 1983). To date, the chronological position of this industry is insecure due to the lack of absolute dating and reliable stratigraphy. Bábonyian lithic tool types are MP type scrapers, bifacial knives, bifacial leaf points, small hand axes and rarely sturdy blade tools of Upper Palaeolithic (UP) types such as the endscraper. Open-air sites with bifacial tools and solely MP tool types were also recorded from the western half of the North Hungarian Range but absolute dating has yet to be performed (Markó 2008-2009).

\section{Middle to Upper Palaeolithic transition}

The beginning of the UP in Hungary long has been related with the Szeletian, which is often classified as an MP-UP transitional industry due to that it contains bifacial leaf points, leaf-shaped bifacial scrapers, endscrapers, UP tools made of blades and retouched and notched flakes (Mester 2014). The eponymous site, Szeleta Cave, located in northeastern Hungary, today is considered inappropriate to represent what the Szeletian is. The main reason is the weak archaeological integrity of most layers that seem to have been reworked by geogenic and biological agents (Lengyel \& Mester 2008). Originally, the Szeletian was divided into two phases, the Early and Upper, and Szeleta Cave was the only site in Central Europe to reveal the two phases in superposition. While the dating of the Upper Szeletian layers at Szeleta Cave is 
insecure (Lengyel \& Mester 2008), the Early Szeletian layers at Szeleta Cave were dated to between 46 and 36 ka uncal BP (Hauck et al. 2016).

\section{Upper Paleolithic}

The earliest UP archaeological entity in Hungary is the Aurignacian. The first site recovered in Hungary was Istállóskő Cave, Bükk Mountains. Excavations in the 1910s by Jenő Hillebrand unearthed the first lithics and after several campaigns of others (O. Kadić, M. Mottl and A. Saád) László Vértes recovered between 1947 and 1951 the two-fold cultural succession what today is widely known from the site (Vértes 1955). Thus, the archaeological sequence contained Aurignacian I (lower layer) and Aurignacian II (upper layer) occupations. The lower layer yielded about a hundred osseous tools complete and fragmented and a few lithic remains. The split base osseous point was the prime character of this assemblage. In the upper layer, the number of osseous tools dwindled, but the lithics were more numerous. Mladeč points (a broadbased point) characterized this osseous industry. Also, a modern human child tooth (permanent molar) was found in the upper layer by Vértes (Tillier at al. 2006). Direct radiocarbon dates obtained from two antler points (not split-based type) from the lower layer ca 35-33 ka uncal BP (Davies \& Hedges 2008-2009) also confirm the Aurignacian chronological position. The upper layer radiocarbon dates 28-30 ka uncal BP on charcoals (Davies \& Hedges 2008-2009) are similar to those obtained from sites yielding broad-based bone points in Moravia, Czech Republic (Wild et al. 2006) and Slovenia (Moreau et al. 2015). Most lithics from the two layers of Vértes are general types such as retouched blades and flakes, end-scrapers and burins, except a very few bifacially shaped tool fragments, and some backed bladelets in the upper layer (Markó 2015). The presence of bifacially shaped tools was often interpreted as a Szeletian intrusion (Vértes 1955), but the backed bladelets clearly signify a Gravettian occupation at Istállóskő (Markó 2015). The pre-Vértes material, which is merged into the upper layer today (Markó 2015), nevertheless, was attributed to the end of the Middle Aurignacian or Upper Aurignacian by the taxonomy of the 1930s, which is today equivalent of the Gravettian. Besides the dominating cave bear, the fauna of the lower layer consist of chamois, reindeer, ibex and bison (Vörös 2003-2004). The upper layer shows a similar spectrum of animals with the addition of elk.

Another dated Early Upper Paleolithic site in Hungary is Peskő Cave near Istállóskő. Peskő is also classified among the Aurignacian sites in Hungary, and by $14 \mathrm{C}$ dates 33.5-38.3 ka uncal BP obtained from osseous artifacts this could be the oldest one (Davies \& Hedges 
2008-2009). However, typologically the osseous tool assemblage is rather undiagnostic, so are the lithic tools that are general UP types lacking any attribute of Aurignacian (Mottl 1942).

The directly dated earliest modern human remain in Hungary that may have belonged to the Aurignacian population was found at Görömböly-Tapolca Cave in Bükk Mountains by G. Megay. The human remain is an occipital bone (Tillier et al. 2006) dated to $30.3 \mathrm{ka}$ uncal BP (Davies \& Hedges 2008-2009). The small lithic assemblage recovered together with the occipital bone is typologically undiagnostic, therefore the cultural affiliation of the site remained unclear.

Characteristic Aurignacian lithic assemblages were reported only from open-air sites yet unexcavated in eastern Hungary, for instance Nagyréde near Mátra Mountains (Chu 2018; Chu et al. 2018; Lengyel et al. 2006). Typologically, the carinated endscraper, nosed endscraper, carinated burin, busked burin and retouched blades are clear characters of the Early Aurignacian.

The Middle UP (MUP) archaeological record in Hungary begins with the Gravettian. The earliest Gravettian occupations were claimed to be as old as 28-26 ka uncal BP and classified Pavlovian or Old Blade Gravettian (Dobosi 2009). The Pavlovian was described as a blade technology that produced mostly burins, end-scrapers, and retouched blades. Backed blades and bladelets, and Gravette/microgravette points compose the minority of the tools. Mammal species from the sites were the reindeer, elk, mammoth and horse. A prominent site from this period is Bodrogkeresztúr in north eastern Hungary.

The Late UP (LUP) period is coeval with the Last Glacial Maximum (LGM) and the subsequent deglaciation period between 21 and $12 \mathrm{ka}$ uncal BP (Dobosi 2009). The human settlements belong to the Ságvárian and Epigravettian cultures. People of both cultures hunted reindeer and horse.

A widely known LGM site in Hungary is Ságvár (the eponym for Ságvárian) where Miklós Gábori (1925-1996) recovered remains of two huts. The Ságvárian culture dated to between 20 and $17 \mathrm{ka}$ uncal BP was characterized by the use of fine grained radiolarite pebbles to obtain UP type tools, therefore a synonym for the Ságvárian was the Pebble Gravettian. The tool types are similar to those found in the Pavlovian, including the backed bladelets. The Epigravettian was defined in Hungary as a descendant of the Gravettian on the basis of the blade technology and the lack of pebble processing in lithic technology (Dobosi 2009). Opposed to the Ságvárian, Epigravettian sites were dated to the end of the LGM and to the whole postLGM period until the terminal Pleistocene. The Epigravettian 18 and $12 \mathrm{ka} \mathrm{BP}$ was divided into two phases (Dobosi 2009): expedient lithic industries between 18 and $16 \mathrm{ka} \mathrm{BP}$, for example 
the site of Jászfelsőszentgyörgy, and backed bladelet dominated industry between 16 and $12 \mathrm{ka}$ BP after Esztergom-Gyurgyalag site. Both Epigravettian phases lack the pebble raw material use and the tool types of the Pavlovian characterized the Epigravettian. A frequently used synonym for the Epigravettian is the Young Blade Gravettian.

During the terminal UP period, Hungary seems to have been rarely populated because the only site is Lovas near Lake Balaton (Sajó et al. 2015). Lovas, dated to ca 11.5-12.0 ka uncal BP was a mineral dyes extraction site that preserved several mining tools made of elk bone. Since the lithic tools are undiagnostic, it is insecure to culturally classify the site.

\section{Key issues/current debates}

Many of the key Paleolithic cave sites of Hungary were excavated in the first half of the $20^{\text {th }}$ century often without producing useful documentation. Also, the large portion of the sediments were removed at these sites and no complete stratigraphic sequences are available to study today. This issue greatly supports debates over the interpretation of their archeological assemblages.

Emerged from this situation, an intensive debate was formulated over Jankovich Cave. The assemblage has a dual character. On the one hand, it contains bifacial leaf tools which match the Late MP (LMP) chronological position and, on the other hand, there is an osseous point component of the assemblage, which generally is related with EUP. These two components of the archaeological record were recently claimed to have been formed together by LMP Neanderthal technology (Markó 2013).

The Jankovich case further touches upon the interpretation of the Istállóskő Cave Aurignacian occupations, where the lithic industries of both layers lack Aurignacian character. Due to the absence of Aurignacian lithic tool types, Markó (2015) found no evidence to classify the lower layer as Aurignacian, and instead suspected a similarity with Jankovich Cave's LMP assemblage containing both bifacial leaf tools and osseous points. Opposed to this, PatouMathis et al. (2016) claimed Istállóskő Cave lower layer is Early Aurignacian since split base points were never found associated at sites having good archeological integrity with cultures other than Aurignacian. The zooarchaeology study by Patou-Mathis et al. (2016) emphasized that the osseous hunting weaponry and the lack of diagnostic Aurignacian lithic tools refer to differences in site function between caves and open-air sites of Aurignacian in Hungary. Istállóskő Cave upper layer, according to Patou-Mathis et al. (2016), is most likely also Aurignacian, based on those few diagnostic artifacts, while Markó (2016) claimed this is the 
only well dated assemblage where leaf shaped tools and Gravettian artifacts were found together.

After several revisions on the archeological sequence at Szeleta Cave, the eponymous site of the Szeletian culture still seems to be inappropriate to represent what Szeletian is. Most likely, the Early Szeletian at Szeleta Cave (layers 3-4) represent the Szeletian of Central Europe (Mester 2014). But, due to the presence of other cultural remains interstratified such as Aurignacian and Gravettian, also to dating anomalies (Lengyel \& Mester 2008; Markó 2016), the assemblages of layers 3 and 4 are most likely impure for technological considerations. The bifacial leaf point collection of the Szeleta Cave layers 3-4 shares was found similar with Jankovich Cave bifacials and therefore there might be a possibility that the Szeletian is an LMP industry (Mester 2017). The Upper Szeletian assemblages (layers 5-6), which contain backed bladelets and Gravette/microgravette points were classified as an industry contemporaneous with the Late Gravettian directly preceding the Last Glacial Maximum (Lengyel et al. 2016). Concerning the putative chronological position of these layers, Markó (2016) found no reason to date these artifacts to the Late Gravettian.

Another debate goes on over the classification of the MUP and LUP in Hungary. The latest research on the lithic assemblages from the period between 28 and $12 \mathrm{ka}$ uncal BP proposed that the first Gravettian settlements can be dated to the Late Gravettian period 25-21 ka uncal BP on the ground of typological similarities with dated sites in Slovakia, Poland, Czech Republic and Austria (Lengyel 2016). Main arguments for a new taxonomy were the lack of Pavlovian artifacts in the assemblages called Pavlovian and the low integrity of the radiocarbon dating results which did not support the claimed chronological position of the Pavlovian assemblages. Concerning the LUP, Lengyel (2016) further proposed to call all LGM sites Early Epigravettian and abandon the term Ságvárian and reclassified sites dated after the LGM under the term Late Epigravettian.

\section{International perspectives and further directions}

As far as the Hungarian Paleolithic research is concerned, the number of projects and the international dissemination of the results is less intense in comparison with other countries of Europe. An important task for the Hungarian research is to enlarge the number of researches with involving wider spectrum of scientific analytical methods for maximizing the quality of the achievements. The territory of Hungary possesses only a fragment of the archaeological record of each Paleolithic hunter-gatherer society in this region. The most effective way, 
therefore, to study and interpret the archaeological record of Hungary is in collaborations with other countries situated on the same foraging territory of Paleolithic hunter-gatherers.

\section{Acknowledgments}

This study was supported by the National Science Center (NCN), Poland decision No. DEC2016/23/P/HS3/04034. This project has received funding from the European Union's Horizon 2020 research and innovation programme under the Marie Skłodowska-Curie grant agreement No 665778 .

\section{References}

Borel, A., V. Dobosi \& M.H. MonCEL. 2017. Neanderthal's microlithic tool production and use, the case of Tata (Hungary). Quaternary International 435/A: 5-20.

DASCHEK, É.J. 2014. Étude archéozoologique des grands mammifères du gisement Paléolithique moyen d'Érd (Hongrie). (BAR International Series 2694.) Oxford.

DAviES, W. \& R. HedGES. 2008-2009. Dating a Type Site: Fitting Szeleta Cave into Its Regional Chronometric Context. Praehistoria 9-10: 35-45.

Dobosi, V.T. 2009. Constancy and Change in Upper Palaeolithic, Hungary, in F. Djindjian, J. Kozłowski \& N. Bicho, (ed.) Le concept de territoires dans le Paléolithique supérieur européen. 15th International Congress of Prehistoric and Protohistoric Sciences (15th: 2006: Lisbon, Portugal), Proceedings of the XV World Congress (Lisbon, 4-9 September 2006): 123133. BAR International Series 1938, Archaeopress, Oxford.

CHU, W. 2018. The Danube Corridor Hypothesis and the Carpathian Basin: Geological, Environmental and Archaeological Approaches to Characterizing Aurignacian Dynamics. Journal of World Prehistory 31/2: 117-178.

Chu, W., G. Lengyel, C. Zeeden, A. PÉntek L. KAminskÁ \& Z. Mester. 2018. Early Upper Paleolithic surface collections from loess-like sediments in the northern Carpathian Basin. Quaternary International 458: 167-182. 
GÁBORI-CsÁNK, V. 1993. Le Jankovichien: Une Civilisation Paléolithiques en Hongrie. Liège, Belgium: ERAUL 53.

Hauck, T.C., J. Richter, W. Chu, O. Vogels, J. Rethemeyer, P. Rentzel, P. Schulte, F. LEHMKUHL, S. HEINZE \& Á. RINGER. 2016. Neanderthals or Early Modern Humans? A Revised 14C Chronology and Geoarchaeological Study of the Szeletian Sequence in Szeleta Cave (Kom. Borsod-Abaúj-Zemplén) in Hungary. Archäologisches Korrespondenzblatt 46: 271-290.

Kele S., A. Markó, J. Cseh, Ch.-Ch. Shen, Ch.-Ch. Wu \& S.M. Bernasconi. 2016. Dating and clumped iso based temperature of the Vértesszőlős travertine and Early Man site (Hungary), in M. Sabol \& O. Žaár (ed.) Lost Worlds of the Stone Age in Travertine. Abstract book of the 5th Geological-Palaeontological-Archaeological Discussion: 14.

Kretzoi, M. \& V.T. Dobosi (ed.). 1990. Vértesszőlös, Man, Site and Culture. Akadémiai Kiadó, Budapest.

Lengyel, G. 2016. Reassessing the Middle and Late Upper Palaeolithic in Hungary. Acta Archaeologica Carpathica 51: 47-66.

LENGYEL, G. \& Z. Mester. 2008. A new look at the radiocarbon chronology of the Szeletian in Hungary. Eurasian Prehistory 5(2), 73-83.

LENGYel, G., S. BÉRES \& L. FodOR. 2006. New lithic evidence of the Aurignacian in Hungary. Eurasian Prehistory 4/1-2: 83-89.

Lengyel, G., Z. MEster \& P. SzOLYÁK. 2016. The Late Gravettian and Szeleta Cave, northeast Hungary. Quaternary International 406/A:174-183.

MARKó, A. 2008-2009. Raw material use at the Middle Palaeolithic site of Vanyarc (Northern Hungary). Praehistoria 9-10: 183-194. 
MARKó, A. 2013. On the Middle Palaeolithic Industry of the Jankovich Cave (Northeastern Transdanubia). Archaeológiai Értesitö 138: 7-28.

MARKÓ, A. 2015. Istállóskő revisited: lithic artefacts and assemblages, sixty years after Acta Archaeologica Academiae Scientiarum Hungaricae 66: 5-38.

MARKó, A. 2016. Considerations on the lithic assemblages from the Szeleta Cave. Communicationes Archaeologicae Hungariae 2015-2016, 5-44.

Mester, Z. 2014. Le Szélétien, in M. Otte (ed.) Néandertal / Cro-Magnon - La Rencontre: 149-188. Arles: Éditions Errance.

Mester, Z. 2017. Considérations sur le Szélétien en Hongrie: la relation du Jankovichien au Szélétien ancien. Anthropologie: International Journal of the Science of Man 55/1-2: 75-92.

Mester, Z. \& M-H. Moncel. 2006. Le site paléolithique moyen d'Érd (Hongrie): nouvelles données sur les chaînes opératoires et résultats morpho-fonctionnels de la production. Anthropologie: International Journal of the Science of Man 44/3: 221-240.

Mester, Z. \& M. PAtou-Mathis. 2016. Nouvelle interprétation des occupations néanderthaliennes de La grotte Subalyuk (Hongrie du nord). Acta Archaeologica Carpathica 51:7-46.

Moreau, L., B. Odar, A. Horvat, T. Higham, P. Turk \& D. Pirkmaier. 2015. Reassessing the Aurignacian of Slovenia: lithic techno-economic behaviour and direct dating of osseous projectile points. Journal of Human Evolution 78: 158-180.

MotTL, M. 1942. Das Aurignacien in Ungarn. Quartär 4: 82-108

Patou-Mathis, M., C. Vercoutère, G. Lengyel, P. Szolyák, \& Z. Mester. 2016. New interpretation of the Upper Palaeolithic human occupations at Istállóskő Cave (Bükk Mountains, Hungary). Eurasian Prehistory 13/1-2: 77-90. 
RINGER, Á. 1983. Bábonyien: Eine mittelpaläolitithische Blattwerkzeugindrustrie in NordostUngarn. Budapest: Eötvös Loránd Tudományegyetem,

Ringer, Á. \& B. AdAMS. 2000. Sajóbábony-Méhésztető, eponymous site of the Middle Paleolithic Bábonyian industry: microwear studies made on tools found at the site during the 1997 excavation. Praehistoria 1: 117-128.

Sajó, I. E., J. Kovács, K.E. Fitzsimmons, V. Jager, G. Lengyel, B. Viola, S. TAlamo \& J-J. Hublin. 2015. Core-Shell Processing of Natural Pigment: Upper Palaeolithic Red Ochre from Lovas, Hungary. PlosOne 10/7: e0131762.

Tillier, A-M., Z. Mester, D. Henry-Gambier, I. PaP, Á. Ringer \& G. Gyenis. 2006. The Middle-Upper Palaeolithic transition in Hungary: an anthropological perspective, in V. Cabrera Valdés, F.B. de Quirós Guidotti \& J.M. Maíllo Fernández (ed.) En el centenario de la Cueva de El Castillo: el ocaso de los Neandertales: Actes du Colloque international: 89-106. Santander: Centro Asociado a la Universidad Nacional de Educación a Distancia en Cantabria.

VÉRTES, L. 1955. Neuere Ausgrabungen und paläolithische Funde in der Höhle von Istállóskő. Acta Archaeologica Academiae Scientarium Hungaricae 5: 111-131.

VÖRÖS, I. 2003-2004. Stratigraphy and biostratigraphy of Istállóskő Cave. Praehistoria 4-5, 33-76.

Wild, E. M., M. Teschler-Nicola, W. Kutschera, P. Steier \& W. WANeK. 2006. 14C dating of early Upper Palaeolithic human and faunal remains from Mladeč, in M. TeschlerNicola (ed.) Early Modern Humans at the Moravian Gate, The Mladeč Caves and their Remains: 149-158. Springer-Verlag, Wien.

\section{List of figures}

Figure 1. Sites mentioned in the text. 1: Vértesszőlős; 2: Tata; 3: Szelim 4: Érd; 5: Jankovich Cave; 6: Remete-Felső Cave; 7: Pilisszántó Rockshelter; 8: Lovas; 9: Ságvár; 10: EsztergomGyurgyalag; 11: Subalyuk Cave; 12: Istállóskő Cave and Peskő Cave; 13: Nagyréde; 14: 
Sajóbábony; 15: Diósgyőr-Tapolca Cave, Görömböly-Tapolca Cave, Szeleta Cave and Balla Cave; 16: Bodrogkeresztúr; 17: Jászfelsőszentgyörgy; 18: Dzeravá skala. Created on OpenStreetMap.

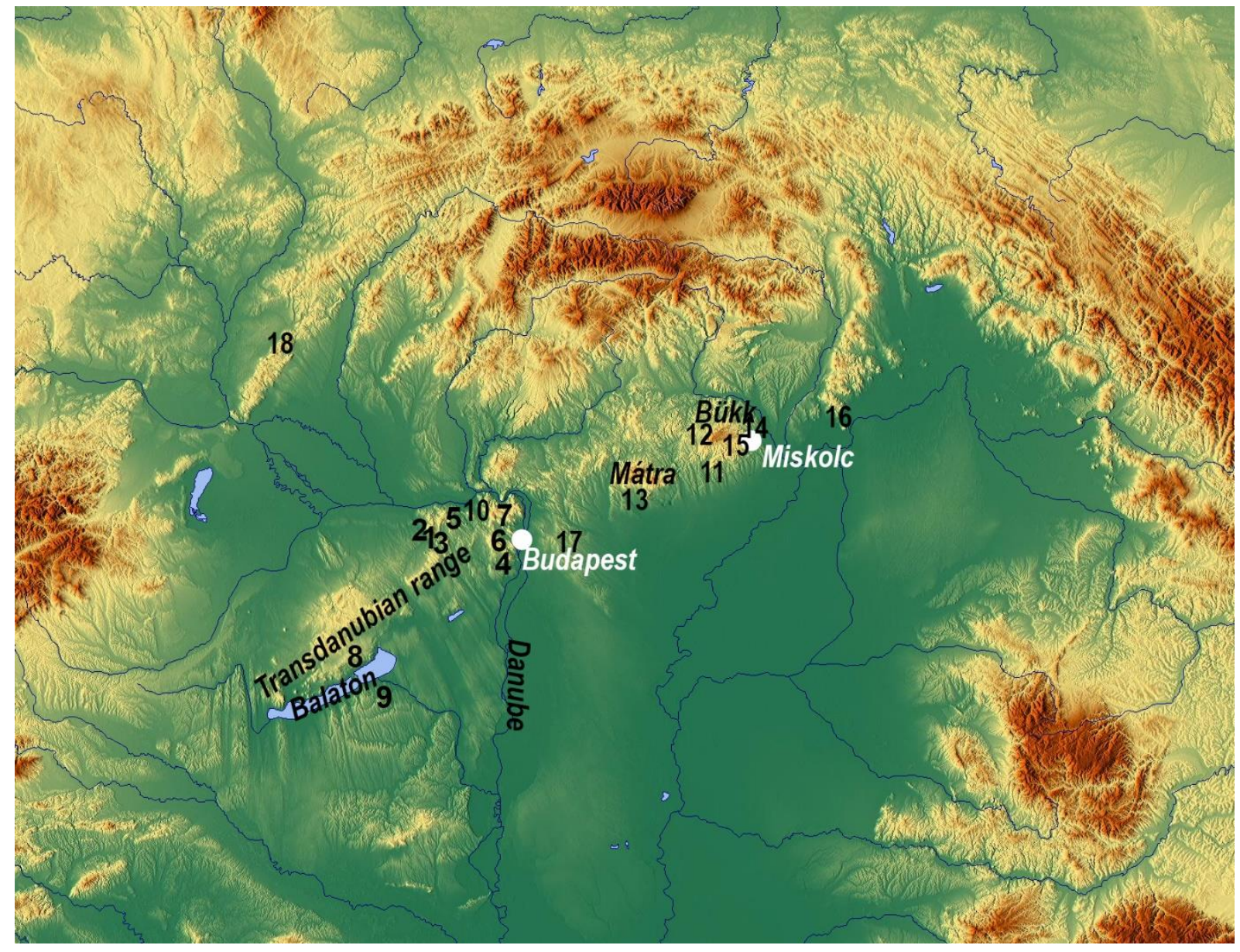

